\title{
Geohelminths in the soil of the Laguna dos Patos in Rio Grande do Sul state, Brazil
}

\author{
I. F. Leon Le (D), A. L. Strothmann $^{a}$ (D), C. L. Islabão ${ }^{b}$ (D), S. Jeske ${ }^{a}$ (D) and M. M. Villela ${ }^{a}$ \\ aPrograma de Pós-graduação em Parasitologia, Instituto de Biologia, Departamento de Microbiologia e Parasitologia, \\ Universidade Federal de Pelotas - UFPel, Campus Universitário Capão do Leão, CEP 96010-900, Pelotas, RS, Brasil \\ ' Instituto de Biologia, Departamento de Microbiologia e Parasitologia, Universidade Federal de Pelotas - UFPel, \\ Campus Universitário Capão do Leão, CEP 96010-900, Pelotas, RS, Brasil \\ *e-mail: italo-leon@hotmail.com
}

Received: April 11, 2019 - Accepted: August 19, 2019 - Distributed: November 30, 2020

(With 3 figures)

\begin{abstract}
This study aimed at examining the prevalence of eggs and larvae of parasites - that may cause diseases to humans and other animals - in the soil of public squares located on the shore of Laranjal beaches, in the Laguna dos Patos, in Pelotas, Rio Grande do Sul state, Brazil. Four fieldwork trips - one per season - were taken to collect samples on six squares built on the shore of these beaches. Five samples of soil were collected on every square on every fieldwork trip. The material was processed by Caldwell \& Caldwell's technique. Four squares $(66.7 \%)$ were positive for helminth eggs and sample positivity was $8.3 \%$ (10). Toxocara spp. and Ancylostoma spp. were the main genera found in these places. Even though prevalence was lower than the one observed by other studies which were carried out in the area, helminths with zoonotic potential were found in the soil of the squares. It should be highlighted that measures to control dogs in these areas must be implemented and public policies must be put forth to make pets' owners and beach goers aware of the need to mitigate environmental contamination.
\end{abstract}

Keywords: Toxocara, Ancylostoma, helminths, environmental contamination.

\section{Geohelmintos no solo da Laguna dos Patos no Estado do Rio Grande do Sul, Brasil}

\begin{abstract}
Resumo
Este estudo teve como objetivo analisar a prevalência de ovos e larvas de parasitos - que podem causar doenças em humanos e outros animais - no solo de praças públicas localizadas na orla das praias do Laranjal, na Laguna dos Patos, em Pelotas, Rio Grande do Sul, Brasil. Quatro viagens de campo - uma por estação - foram realizadas em seis praças construídas na orla dessas praias. Cinco amostras de solo foram coletadas por praça em cada saída de campo. O material foi processado pela técnica de Caldwell e Caldwell. Quatro praças (66,7\%) foram positivas para ovos de helmintos e a positividade da amostra foi de 8,3\% (10). Toxocara spp. e Ancylostoma spp. foram os principais gêneros encontrados nesses locais. Embora a prevalência tenha sido menor que a observada por outros estudos realizados na área, helmintos com potencial zoonótico foram encontrados no solo das praças. Deve-se ressaltar que medidas para o controle de cães nessas áreas devem ser implementadas e políticas públicas devem ser concretizadas para tornar os donos de animais de estimação e frequentadores destas praias, conscientes da necessidade de mitigar a contaminação ambiental.
\end{abstract}

Palavras-chave: Toxocara, Ancylostoma, helmintos, contaminação ambiental.

\section{Introduction}

About five billion people worldwide have been at risk of infections transmitted by parasites found in the soil - or whose biological cycle partially occurs in the soil -, called geohelminths (Pullan and Brooker, 2012). These parasites play an important role in the contamination of public places, such as squares, beaches and parks (Pullan et al., 2011; Pullan and Brooker, 2012; Nooraldeen, 2015).

It has been more common to see dogs and cats as pets these days. These animals, mainly stray ones, are potential transmitters of parasites that cause zoonoses to humans (Campos Filho et al., 2008; Cassenote et al., 2011). Helminths of genera Ancylostoma spp., Dipylidium sp. and Toxocara spp. are some examples of parasites transmitted by animals' feces; their eggs and larvae may keep in the environment for a long time and, consequently, affect humans' health (Labruna et al., 2006; Marques et al., 2012). It becomes a serious problem for children since they have direct contact with contaminated soil and less 
care for hygiene, a fact that makes them put their hands and toys in their mouths when they play on the ground. Besides, larvae of parasites may penetrate into their bodies through the skin (Moura et al., 2013; Kumapley et al., 2015; Periago et al., 2015).

Studies carried out worldwide have shown different indexes of soil positivity on squares and recreation areas as the result of parasites that have zoonotic potential (Tarsitano et al., 2010; Saraei et al., 2012; Blaszkowska et al., 2013). A study of sand samples from Laranjal beaches which was conducted about two decades ago showed positivity in $9.5 \%$ of samples under analysis, i. e., eggs of Toxocara spp., hookworms, Trichuris spp. and Ascaris spp. were found (Villela et al., 2009).

Therefore, after almost two decades, it is important to examine the prevalence of eggs and larvae of parasites that may cause diseases to humans and other animals - in the soil of public squares located on Laranjal beaches, in the Laguna dos Patos, Pelotas, RS, Brazil.

\section{Methodology}

\subsection{Area of study}

This study was carried out in Pelotas, RS, Brazil, on six public squares built on the shore of Laranjal beaches (31 76 '22.4”S 52 22'76.9'W - Figure 1), called Santo Antônio and Valverde. The area of study, which stretches over 1,900 meters $(1.9 \mathrm{~km})$, is one of the most visited places in the Laguna dos Patos.

\subsection{Study design}

Areas which were visited by the population in search for leisure and recreation for children were selected. Besides, pet and stray dogs have free access to these places.

\subsection{Collection of soil samples}

Fieldwork trips were taken in the morning, in March 2016, June 2016, December 2016 and October 2017. Five spots were selected on each of the six squares under study (Figure 2) for the collection of soil samples. Priority was given to the most visited places on the squares, such as the playground (around swings and slides) and benches. Samples $(200 \mathrm{~g})$ were collected by superficial soil scraping $(2 \mathrm{~cm})$ with a spatula, put into plastic bags, identified and taken to the laboratory of Human Parasitology in the Biology Institute at the Universidade Federal de Pelotas (UFPel) for analysis. It should be highlighted that certain characteristics, such as stray dogs and pet ones, with their owners, barriers that prevented animals from accessing the place and feces in the environment, were observed. Another factor that was taken into consideration was the frequency in which every square was positive.

Processing and analysis of soil samples: Caldwell \& Caldwell's technique adapted by Pessoa and Martins (1988) was applied to diagnose parasitic forms. Aliquots of $6 \mathrm{~g}$ soil (every sample) were weighed and diluted in $10 \mathrm{~mL}$ chlorinated solution (4-6\% sodium hypochlorite diluted in $30 \%$ distilled water). The sample was then filtered through gauze, placed into a $15-\mathrm{mL}$ test tube and centrifuged at 2000 RPM for two minutes. Afterwards, the supernatant was discarded and $10 \mathrm{~mL}$ sodium dichromate ( $\mathrm{D}=1.35 \mathrm{mg} / \mathrm{DL}$ ) was added. The solution was centrifuged again at 1500 RPM for three minutes.

Finally, the tube was filled with sodium dichromate solution so as to form the meniscus on which the coverslip is placed. After two hours - time needed for the suspension of the material up to the coverslip -, samples were read by an optical microscope, at 10x and 40x magnification.

Data analysis: Slides were read and results were expressed by descriptive statistics. Values were described as frequency (observed value - $n$ ), organized in tables and analyzed by the Microsoft Excel ${ }^{\circledR}$ program. Statistical comparison among groups (positivity on squares, dogs on the site, feces when samples were collected, parasites in the soil) was carried out by the chi-square test $\left(\chi^{2}\right)$ and values $\mathrm{p} \leq 0.05$ were considered significant.

\section{Results}

Ten out of 120 samples prepared for reading were positive, which meant $8.3 \%$. Regarding general positivity in the fieldwork, two squares (4 and 5) were found to be

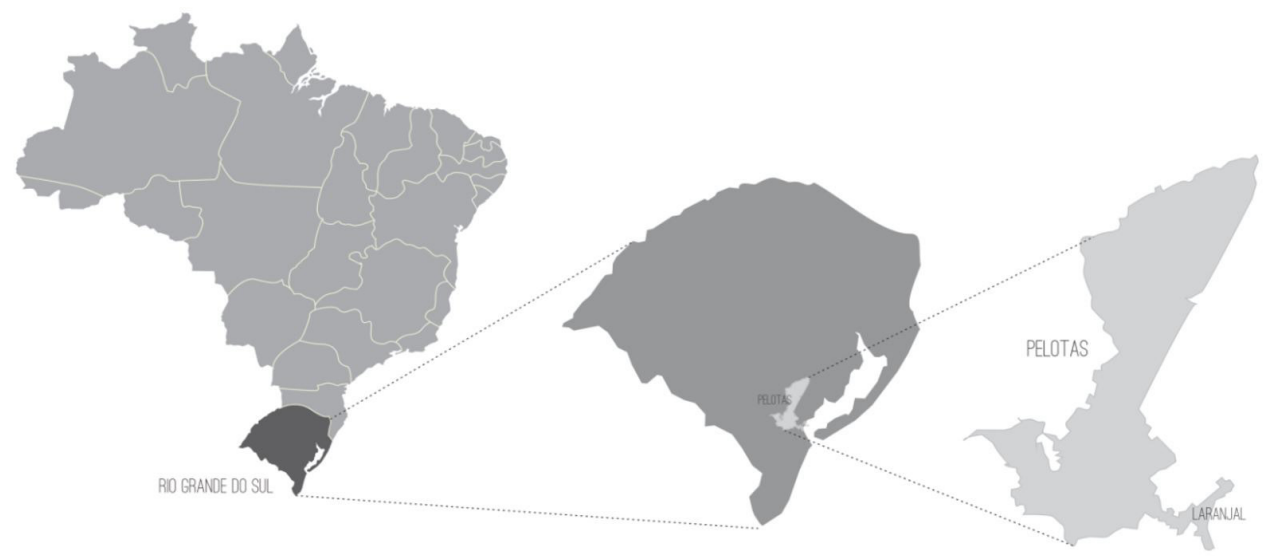

Figure 1. Map of Brasil, Rio Grande do Sul state, southern Brazil, showing the location of the Pelotas and the Laranjal. 


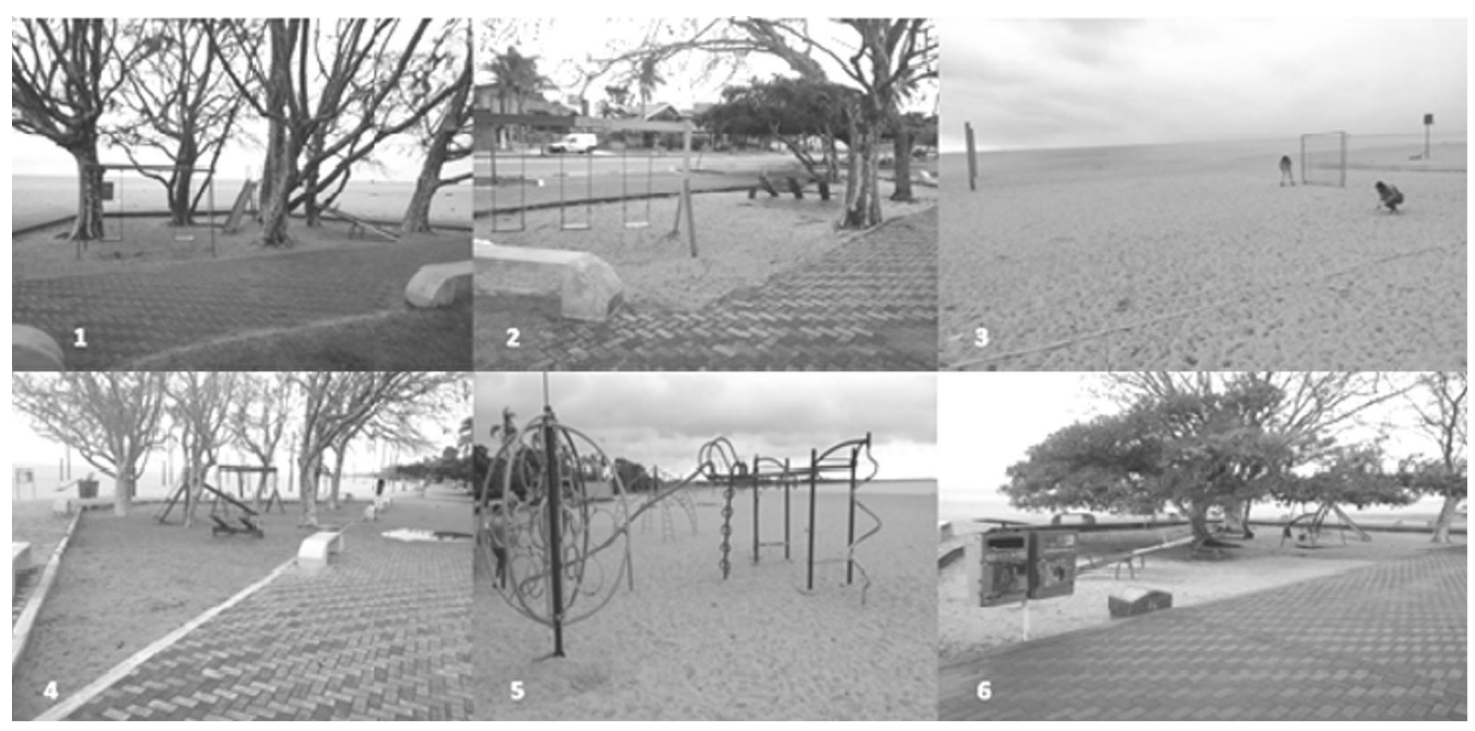

Figure 2. Six squares on the shore of Laranjal beaches, in the Laguna dos Patos, Pelotas, RS, Brazil, where parasites were evaluated in the soil.

Table 1. Data on stray dogs and animal feces collected on fieldwork trips to squares located on the shore of Laranjal beaches, in the Laguna dos Patos, Pelotas, RS, Brazil.

\begin{tabular}{|c|c|c|c|c|}
\hline \multirow{2}{*}{ Squares } & $1^{\circ}$ Fieldwork trip & $2^{\circ}$ Fieldwork trip & $3^{\circ}$ Fieldwork trip & $4^{\circ}$ Fieldwork Trip \\
\hline & Dogs Feces & Dogs Feces & Dogs Feces & Dogs Feces \\
\hline 01 & +- & -+ & ++ & +- \\
\hline 02 & -+ & ++ & -- & -+ \\
\hline 03 & +- & -- & - - & -- \\
\hline 04 & ++ & -+ & +- & ++ \\
\hline 05 & ++ & -+ & ++ & -+ \\
\hline 06 & +- & ++ & -+ & ++ \\
\hline
\end{tabular}

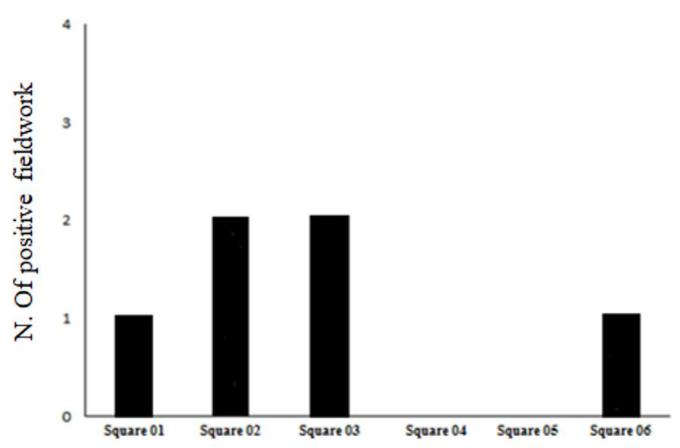

Figure 3. Frequency of positivity of relevant helminths in health, considering the number of fieldwork trips (axis $y$ ) to six public squares (axis $x$ ) on the shore of Laranjal beaches, in the Laguna dos Patos, Pelotas, RS, Brazil.

free from parasitic contamination by the techniques under analysis (Figure 3), whereas the others (66.7\%) exhibited medically important parasite eggs in at least one out of four collections.

Considering 10 positive samples, 50\% (5) had hookworm eggs, $40 \%$ (4) had Toxocara spp. eggs and 10\% (1) had Toxascaris sp. eggs. It should be pointed out that stray dogs, as well as feces, were seen on the squares on all fieldwork trips (Table 1). There were no physical barriers, such as fences, screens and containment structures, to restrict the access of dogs to the squares in any area under study (Figure 2). Square 3 was the only one where feces where not seen on the fieldwork trips, but the statistical methods under use found no significant difference among variables - feces, dogs and parasites in the soil.

Concerning positivity in relation to months under investigation, the highest one was found on the fieldwork trip conducted in June (in winter), i. e., six sand samples were positive.

\section{Discussion}

Studies of frequency of parasites in the soil found in different Brazilian regions and in the world have shown environmental contamination of public places, mainly in regions where there is poor sanitation (Maikai et al., 2008; Santarém et al., 2009; Mello et al., 2011; Lima et al. 2017). This study shows that the contamination index of public squares on the shore of Laranjal beaches was $8.3 \%$ whereas a previous study carried out on the same site found $9.5 \%$ positivity in the soil (Villela et al., 2009). Therefore, even 
after two decades, parasites with zoonotic potential were found in that environment.

Comparison between results of this study and the ones of the research conducted by Prestes et al. (2015), who found $41 \%$ positivity in the soil of public squares in six cities in the south of Rio Grande do Sul state, shows that environmental contamination is lower on the squares located on these beaches in the Laguna dos Patos. A reason could be the fact that new layers of sand were placed on the squares investigated by this study; thus, feces and their traces were buried and environmental contamination was restricted. In addition, because these beaches, which are part of the Laguna dos Patos, are important touristic spots in the south of Rio Grande do Sul state, they have their squares often cleaned, mainly in summer.

Even though there is little difference between Toxocara spp. and hookworms regarding eggs in the environment, the latter were more frequent. It corroborates other studies that state that this group is the most common parasite in dogs and cats (Blazius et al., 2005; Leite et al., 2006; Hernández Merlo et al., 2007; Marques et al., 2012; Lima et al., 2014). Finding eggs of these parasites means that there are infected cats and dogs which wander around these places (Okoye et al., 2011; Prestes et al., 2015; Maciel et al., 2016).

In Pelotas downtown, public squares have also been evaluated regarding parasitic contamination. They had high levels of parasites of interest to public health (Moura et al., 2013 ) and their positivity was significantly higher (44\%) than the one found by this study $(8.3 \%)$. The authors pointed out that contamination is directly related to stray dogs and cats' feces, since the high population of these animals in the city results in increase in infectious forms of helminths in the soil (Prestes et al., 2015).

Concerning the seasons, this study found that June was the month with the highest environmental contamination. It corroborates the study carried out by Habluetzel et al. (2003), who observed that environmental contamination was higher in the coldest months of the year. It may be due to the fact that authorities are rather negligent and do not show concern for these places in winter, when there are fewer users.

\section{Conclusion}

Results of this study show that, even though the environmental contamination index by parasites of interest to public health was moderate, there is still risk of infection in the areas under evaluation. Constant monitoring of structural care for these squares is needed, besides control and treatment of stray dogs, i. e., the administration of anthelminthic drugs and the implementation of castration programs.

Another basic issue refers to the use of educational projects which aim at making users of these recreational areas more aware of the situation. Thus, specific educational material should be edited with suggestions, such as cleaning children's hands, feet and toys after they leave the playground, collecting trash and removing food remains from the squares. These are simple measures which are capable of decreasing the likelihood of environmental contamination and infection by parasites significantly.

\section{References}

BLASZKOWSKA, J., WOJCIK, A., KURNATOWSKI, P. and SZWABE, K., 2013. Geohelminth egg contamination of children's play areas in the city of Lodz (Poland). Veterinary Parasitology, vol. 192, no. 1-3, pp. 228-233. http://dx.doi. org/10.1016/j.vetpar.2012.09.033. PMid:23084538.

BLAZIUS, R.D., EMERICK, S., PROPHIRO, J.S., ROMÃO, P.R.T. and SILVA, O.S., 2005. Ocorrência de protozoários e helmintos em amostras de fezes de cães errantes da Cidade de Itapema, Santa Catarina. Revista da Sociedade Brasileira de Medicina Tropical, vol. 38, no. 1, pp. 73-74. http://dx.doi. org/10.1590/S0037-86822005000100018. PMid:15717103.

CAMPOS FILHO, P.C., BARROS, L.M., CAMPOS, J.O., BRAGA, V.B., CAZORLA, I.M., ALBUQUERQUE, G.R. and CARVALHO, S.M.S., 2008. Parasitas zoonóticos em fezes de cães em praças públicas do município de Itabuna, Bahia, Brasil. Revista Brasileira de Parasitologia Veterinária, vol. 17, no. 4, pp. 206-209. http://dx.doi.org/10.1590/S1984-29612008000400007. PMid:19265579.

CASSENOTE, A.J.F., PINTO NETO, J.M., LIMA-CATELANI, A.R.A. and FERREIRA, A.W., 2011. Contaminação do solo por ovos de geo-helmintos com potencial zoonótico na municipalidade de Fernandópolis, Estado de São Paulo, entre 2007 e 2008. Revista da Sociedade Brasileira de Medicina Tropical, vol. 44, no. 3, pp. 371-374. http://dx.doi.org/10.1590/S0037-86822011005000026. PMid:21552740

HABLUETZEL, A., TRALDI, G., RUGGIERI, S., ATTILI, A.R., SCUPPA, P., MARCHETTI, E.F., MENGHINI, G. and ESPOSITO, F., 2003. An estimation of Toxocara canis prevalence in dogs, environmental egg contamination and risk of human infection in the Marche region of Italy. Veterinary Parasitology, vol. 113, no. 3-4, pp. 243-252. http://dx.doi.org/10.1016/S03044017(03)00082-7. PMid:12719139.

HERNÁNDEZ MERLO, R., FIDEL NÚÑEZ, A. and PELAYO DURÁN, L., 2007. Potencial zoonótico de las infecciones por helmintos intestinales en perros callejeros de Ciudad de La Habana. Revista Cubana de Medicina Tropical, vol. 59, no. 3, pp. 234-240. PMid:23427462.

KUMAPLEY, R.S., KUPKA, R. and DALMIYA, N., 2015. The role of child health days in the attainment of global deworming coverage targets among preschool-age children. Public Library of Science Neglected Tropical Disease, vol. 9, no. 11, pp. 6-9. http://dx.doi.org/10.1371/journal.pntd.0004206. PMid:26544550.

LABRUNA, M.B., PENA, H.F.J., SOUZA, S.L.P., PINTER, A., SILVA, J.C.R., RAGOZO, A.M.A., CAMARGO, L.M.A. and GENNARI, S.M., 2006. Prevalência de endoparasitas em cães da área urbana do município de Monte Negro, Rondônia. Arquivos do Instituto Biológico, vol. 73, pp. 183-193.

LEITE, L.C., BANDEIRA, C.R.B., CIRIO, S.M., LUZ, E., DINIZ, J.M.F., LEITE, S.C., LUNELLI, D., WEBER, S. and COELLI, C.R.V.R., 2006. Ocorrência de ovos de Ancylostoma spp. e Trichuris spp. em fezes de cães em meia-praia, Itapema, Santa Catarina, Brasil. Revista Estudos de Biologia, vol. 28, no. 65, pp. 105-110. http://dx.doi.org/10.7213/reb.v28i65.22744. 
LIMA, F.S., SILVA, T., CARVALHO, A.C.F., DIAS, P.M., RAMOS, C.D. and BATISTA, L.C.D.S.O., 2017. Contaminação ambiental por ovos de Ancylostoma spp. e Toxocara spp. em áreas de seis praças públicas do município de Valença, Estado do Rio de Janeiro. Acta Biomedica Brasiliensia, vol. 8, no. 1, pp. 35-42. http://dx.doi.org/10.18571/acbm.120.

LIMA, V.F.S., SANTOS, T.D.J., BEZERRA, T.L., SANTOS, M.S. and SANTOS, P.O.M., 2014. Helmintozoonoses e protozoonoses caninas no bairro Rosa Elze, São Cristóvão/Sergipe - Brasil. Enciclopédia Biosfera, vol. 10, no. 19, pp. 1134-1145.

MACIEL, J.S., ESTEVES, R.G., SOUZA, M.A.A., 2016. Prevalência de helmintos em areias de praças públicas do município de São Mateus, Espírito Santo, Brasil. Natureza on line, vol. 14, no. 2, pp. 15-22.

MAIKAI, B.V., UMOH, J.U., AJANUSI, O.J. and AJOGI, I., 2008. Public health implications of soil contaminated with helminth eggs in the metropolis of Kaduna, Nigéria. Journal of Helminthology, vol. 82, no. 2, pp. 113-118. http://dx.doi. org/10.1017/S0022149X07874220. PMid:18201389.

MARQUES, J.P., GUIMARÃES, C.R., VILAS BOAS, A., CARNAÚBA, P.U. and MORAES, J., 2012. Contamination of public parks and squares from Guarulhos (São Paulo State, Brazil) by Toxocara spp. and Ancylostoma spp. Revista do Instituto de Medicina Tropical de São Paulo, vol. 54, no. 5, pp. 267-271. http:// dx.doi.org/10.1590/S0036-46652012000500006. PMid:22983290.

MELLO, C.S., MUCCI, J.L.N. and CUTOLO, S.A., 2011. Contaminação parasitária de solo em praças públicas da zona leste de São Paulo, SP - Brasil e a associação com variáveis meteorológicas. Revista de Patologia Tropical, vol. 40, no. 3, pp. 253-262. http://dx.doi.org/10.5216/rpt.v40i3.15976.

MOURA, M.Q., JESKE, S., VIEIRA, J.N., CORRÊA, T.G., BERNE, M.E.A. and VILLELA, M.M., 2013. Frequency of geohelminths in public squares in Pelotas, RS, Brazil. Revista Brasileira de Parasitologia Veterinária, vol. 22, no. 1, pp. 175178. http://dx.doi.org/10.1590/S1984-29612013000100034. PMid:24252968.

NOORALDEEN, K., 2015. Contamination of public squares and parks with parasites in Erbil city, Iraq. Annals of Agricultural and Environmental Medicine, vol. 22, no. 3, pp. 418-420. http://dx.doi. org/10.5604/12321966.1167705. PMid:26403106.

OKOYE, I.C., OBIEZUE, N.R., OKORIE, C.E. and OFOEZIE, I.E., 2011. Epidemiology of intestinal helminth parasites in stray dogs from markets in south-eastern Nigeria. Journal of Helminthology, vol. 85, no. 4, pp. 415-420. http://dx.doi. org/10.1017/S0022149X10000738. PMid:21144127.
PERIAGO, M., DINIZ, R.C., PINTO, S.A., YAKOVLEVA, A., CORREA-OLIVEIRA, R., DIEMERT, D.J. and BETHONY, J.M., 2015. The right tool for the job: detection of soil-transmitted helminths in areas co-endemic for other helminths. Public Library of Science Neglected Tropical Disease, vol. 9, no. 8, pp. e0003967. http://dx.doi.org/10.1371/journal.pntd.0003967. PMid:26241329.

PESSOA, S.B. and MARTINS, A.V., 1988. Noções sobre as principais técnicas usadas em parasitologia. In: S.B. PESSOA and A.V. MARTINS. Parasitologia médica. 11. ed. Rio de Janeiro: Guanabara Koogan, pp. 814-854.

PRESTES, L.F., JESKE, S., SANTOS, C.V., GALLO, M.C. and VILLELA, M.M., 2015. Contaminação do solo por geohelmintos em áreas públicas de recreação em municípios do sul do Rio Grande do Sul (RS), Brasil. Revista de Patologia Tropical, vol. 44, no. 2, pp. 155-162. http://dx.doi.org/10.5216/rpt.v44i2.36645.

PULLAN, R.L. and BROOKER, S., 2012. The global limits and population at risk of soil-transmitted helminth infections in 2010. Parasites \& Vectors, vol. 5, no. 1, pp. 81. http://dx.doi. org/10.1186/1756-3305-5-81. PMid:22537799.

PULLAN, R.L., GETHING, P.W., SMITH, J.L., MWANDAWIRO, C.S., STURROCK, H.J.W., GITONGA, C.W., HAY, S.I. and BROOKER, S., 2011. Spatial modelling of soil-transmitted helminth infection in kenya: a disease control planining tool. Public Library of Science Neglected Tropical Disease, vol. 5, no. 2, pp. e958. http://dx.doi.org/10.1371/journal.pntd.0000958. PMid:21347451.

SANTARÉM, V.A., ELEFANT, G.R., CHESINE, P.A.F. and LELI, F.N.G., 2009. Toxocaríases canina e humana. Veterinária e Zootecnia, vol. 16, pp. 437-447.

SARAEI, M., ZAKILO, M., TAVAZOEI, Y., JAHANIHASHEMI, H. and SHAHNAZI, M., 2012. Contamination of soil and grass to Toxocara spp. eggs in public parks of Qazvin, Iran. Asian Pacific Journal of Tropical Biomedicine, vol. 2, no. 2, pp. 1156-1158. http://dx.doi.org/10.1016/S2221-1691(12)60377-3.

TARSITANO, E., GRECO, G., DECARO, N., NICASSIO, F., LUCENTE, M.S., BUONAVOGLIA, C. and TEMPESTA, M., 2010. environmental monitoring and analysis of faecal contamination in an urban setting in the city of Bari (Apulia Region, Italy): health and hygiene implications. International Journal of Environmental Research and Public Health, vol. 7, no. 11, pp. 3972-3986. http://dx.doi.org/10.3390/ijerph7113972. PMid:21139871.

VILLELA, M.M., PEPE, M.S., FERRAZ, M.L., MORAIS, N.C.M., ARAÚJO, A.B., RUAS, J.L., MULLER, G. and BERNE, M.E.A., 2009. Nota: contaminação ambiental da orla da Laguna dos Patos (Pelotas, RS, Brasil), por parasitos com potencial zoonótico. Vittalle, vol. 21, no. 2, pp. 69-74. 